\title{
Effect of Calving Season, Calving Year and Lactation Number on the Milk Yield Traits in Holstein Cows Raising in Şanlıurfa
}

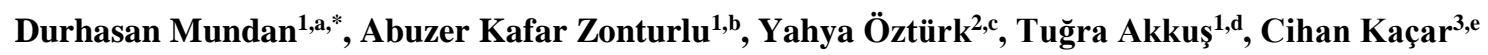 \\ ${ }^{1}$ Faculty of Veterinary Medicine, Harran University, 63000 Şanliurfa, Turkey \\ ${ }^{2}$ Burdur Vocational School, Mehmet Akif Ersoy University, 15030 Burdur, Turkey \\ ${ }^{3}$ Faculty of Veterinary Medicine, Kafkas University, 36100 Kars, Turkey \\ *Corresponding author
}

\begin{tabular}{l|l}
\hline A R T I C L E I N F O & A B S T R A C T \\
\hline $\begin{array}{l}\text { Research Article } \\
\text { Received : 02/10/2019 }\end{array}$ & $\begin{array}{l}\text { The aim of the present study is to investigate the impact of some environmental factors on the } \\
\text { descriptive values of milk yield characteristics in Holstein cows. For this purpose, a total of 241 } \\
\text { lactations belonging to } 62 \text { Holstein cows had been kept as breeders in a private establishment were } \\
\text { evaluated for } 7 \text { years in terms of milk yield. When the recording system of the establishment was } \\
\text { examined, the average values of lactation yield (LY), corrected 305 day milk yield (305-dMY), } \\
\text { average daily milk yield (ADMY) and lactation length (LL) were 9356.2 } 126.1 \mathrm{~kg}, 8549.2 \pm 105.8 \\
\text { kg, 28.0 } \pm 0.3 \mathrm{~kg} \text { and } 315.0 \pm 2.3 \text { days, respectively. The least mean squares (LMS) of LY was } \\
\text { calculated as 9324.9 kg. It was found that the effect of the calving season on the LY was statistically } \\
\text { significant (P<0.05), while its effect on the 305-dMY, ADMY and LL was insignificant. The effect } \\
\text { of the calving interval on LY, 305-dMY and ADMY was statistically significant (P<0.001). As a } \\
\text { result, it is concluded that calving season, year and lactation number affect the LY traits in Holstein } \\
\text { cows and it is understood that pregnant Holstein cows import from Germany are more adaptable to } \\
\text { the region under appropriate environmental conditions along with overall herd health and } \\
\text { management. }\end{array}$ \\
$\begin{array}{l}\text { Keywords: } \\
\text { Herd health management } \\
\text { Holstein } \\
\text { Lactation number } \\
\text { Milk yield characteristics }\end{array}$ &
\end{tabular}

Lactation number
Milk yield characteristics

management.

b@azonturlu@harran.edu.tr d@tugraakkus08@hotmail.com

(iD) http://orcid.org/0000-0002-9537-5117 (iD) http://orcid.org/0000-0002-6002-5942

\section{Introduction}

Holstein is the most common population of the culture breeds grown in Turkey. It has been imported in order to supply male and female animal stock for breeding studies (Alpan and Aksoy, 2015). The most important of these includes the studies done to control the yield and to establish and improve the pedigree system.

The most effective way of achieving profitability in dairies is a well-established herd-health management. Factors that influence milk yield for low-cost milk production in establishments and determination of their impact on milk yield and quality in the positive or negative direction are among the priority issues. This activity is possible in businesses that keep regular and accurate records. The Holstein breed is preferred by breeders because of the high milk yield, good fattening performance and rather less difficulty in adaptation and success in breed selection can be achieved through proper record-keeping. FAO (2018) reports that the average milk yield obtained per lactating animal is $9.219 \mathrm{~kg}$ in the USA, $6012 \mathrm{~kg}$ in EU countries, while it is reported between 5.000 and $7.000 \mathrm{~kg}$ in Turkey.

Age and lactation number in cows are among the other important factors affecting milk yield. With the increase in the lactation numbers, improved milk yield is observed. Milk yield which is low in the first lactation, increases with each passing year. This increase continues until the age of maturity (6-8 years). When the cow reaches the age of 8-9, the milk yield starts to decrease and its use as breeding cow ends (Ali et al., 1996; Lackovic et al., 1995; Polanski et al., 1993). There are other studies investigating the effects of 
other factors such as age (Souza et al., 1996; Thaler Neto et al., 1996) and the duration of lactation (Afifi et al., 1994; Ali et al., 1996; Udedibie et al., 1985). According to the results of age-related research, a heifer at 2 years old gives approximately $70-75 \%$ of adult milk yield, $80-85 \%$ at second calving, and $90-95 \%$ at third and fourth calving (Alpan and Aksoy, 2015).

In terms of nutritional factors in cows, animals must be fed in an adequate and balanced manner so that milk can be obtained from dairy cows in desired quantities. No matter how good the breed of the animal is, the milk yield is low if the animal cannot be fed adequately and balanced, and if sufficient water requirements cannot be met. In the first and second lactations, the quality and quantity of the ratio should be adjusted considering the age and body growth together along with the efficiency share (Alpan and Aksoy, 2015; Uğur, 2014).

A large number of studies have been conducted in order to determine several productivity characteristics and environmental factors that affect them in Holstein breed cattle grown in Turkey (Afifi et al., 1994; Ajili et al., 2007; Akkaş, 2008; Ali et al., 1996; Bakır and Çetin, 2003; Bayrıl and Y1lmaz, 2010; Bayril and Y1lmaz, 2017; İnci et al., 2007; Lackovic et al., 1995; Udedibie et al., 1985). The purpose of this study was to determine the descriptive values of milk production characteristics of Holstein cows grown in a private milk establishment in Şanlıurfa province and to reveal their performances in the region.

\section{Materials and Method}

\section{Location and Materials}

Şanliurfa is located at 3749 '12 "- 40 10' 00" east longitude and 3641 '28 "- 37 57' 50" north latitudes in the Southeastern Anatolia Region of Turkey. It has elevation of 546.85 meters above sea level.

The present study investigated the distribution of milk yield characteristics according to years and seasons of a total of 62 cows (2-9 age) who were imported from Germany as pregnant and were raised as breeders in Şanlıurfa province centre. Computer registry data were examined and healthy cows which had normal birth, did not have any reproductive disorder, and did not have a postpartum problem were used as the research material.

The rations of cows are carried out twice a day with feed mix and spreading wagons. The ration levels of the feeds were arranged to balance the ratios given in Table 1.

Table 1. Ratio levels of feed given to Holstein cows.

\begin{tabular}{l|c}
\multicolumn{1}{c|}{ Feed Type } & Amount $(\mathrm{kg})$ \\
\hline Dried clover & 3 \\
Corn silage & 25 \\
Wheat starch & 1 \\
Wheat bran & 1 \\
Ground corn & 5.5 \\
CSM & 1.7 \\
Soybean paste residue & 2.7 \\
Vitamins and minerals & 0.05 \\
Marble powder & 0.13 \\
NaHCO & 0.05 \\
Salt & 0.01 \\
\hline CSM: Cotton Seed Meal
\end{tabular}

Cows were monitored for presence of estrus by pedometer and artificial insemination was applied to those in which clinical signs of estrus were observed. The calves were fed for 3 months in separate paddocks after birth. The cows were automatically enrolled in the individual daily milk production computer system by milking with the Rotary milking system twice a day, at intervals of 12 hours. Animals were kept in semi-open and free-standing stables. In the stables, rubber beds were used as bedplate. There were scratching brushes for animal welfare. Shadows against heat stress and water mist nozzle installations with the fan system were used.

\section{Statistical Analysis}

The descriptive values of the milk yield characteristics of cows and the impacts of environmental factors were determined by the LMS method. The significance control of the differences between the group averages and their comparison were made using the General Linear Model (GLM) in the SPSS package program.

For this purpose, Yijkl $=\mu+a i+b j+c k+b X i j k+$ eijklm was used as a model in the analysis of the environmental factors affecting the milk yield characteristics.

Terms refer to;

Yijkl = observation value of the milk yield characteristic,

Yijklm $=\mathrm{i}$. calving season, $\mathrm{j}$. lactation number, $\mathrm{k}$. calving year,

$\mu \quad=$ Population average, (general average),

ai $=\mathrm{i}$. the impact of the calving season (1: Winter, 2: Spring, 3: Summer, 4: Autumn),

bj $\quad=\mathrm{j}$. the impact of the number of lactation

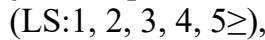

$\mathrm{ck}=\mathrm{k}$. the impact of the year of calving $(1,2,3$, $4,5,6,7 \geq)$,

$\mathrm{bXijk}=\mathrm{i}$. season, $\mathrm{j}$. number of lactation, $\mathrm{k}$. year,

$\mathrm{b} \quad=$ partial regression coefficient of the corresponding characteristic of the lactation length,

eijklm = impact of error.

\section{Results}

Descriptive statistical values of milk yield characteristics are given in Table 2 . The highest coefficient of variation (CV) $(20.9 \%)$ belongs to $\mathrm{LV}$; the lowest $\mathrm{CV}$ (7.5\%) belongs to LL. The calculated CV of milk yield, regardless of LL, was $26 \%$.

Results of LMS, significance test regarding LY, 305$\mathrm{dMY}, \mathrm{ADMY}$ and LL are given in Table 3. Only the effect on calving year $(\mathrm{P}<0.001) 305-\mathrm{dMY}$ was found significant.

305-dMY and ADMY were found to be statistically insignificant although cows that gave birth in the spring were numerically higher than those who gave birth in other seasons. It was observed that the effect of LY was statistically significant when the effect of calving season $(\mathrm{P}<0.05)$ and the year of calving $(\mathrm{P}<0.001)$ were examined.

The results of LMS, significance and multiple comparison test of LL are given in Table 3. According to this table, the average duration of lactation was 315.0 days. This value is 13.4 days shorter than the expected value, 305 days. Calving season, calving year and lactation number factors were not significant on LL. 
Table 2. Descriptive statistics of milk yield characteristics in Holstein cows.

\begin{tabular}{l|cccccc}
\hline \multicolumn{1}{c}{ Characters } & $\mathrm{N}$ (Number of records) & $\mathrm{X} \pm \mathrm{S}_{\mathrm{x}}^{-}$ & Min & Max & $\mathrm{CV}(\%)$ & Variance \\
\hline LY $(\mathrm{kg})$ & 241 & $9356.2 \pm 126.1$ & 3000 & 13942 & 20.9 & 3833503.7 \\
305-dMY $(\mathrm{kg})$ & 241 & $8549.2 \pm 105.8$ & 3000 & 13478.1 & 19.2 & 2699633.4 \\
ADMY $(\mathrm{kg})$ & 241 & $28.0 \pm 0.3$ & 9.84 & 44.2 & 19.2 & 29.0 \\
LL (day) & 241 & $315.0 \pm 2.3$ & 261 & 355 & 7.5 & 573.0 \\
\hline
\end{tabular}

Table 3. The LMS values of LY, 305-dMY and LL.

\begin{tabular}{|c|c|c|c|c|c|}
\hline \multirow{2}{*}{ Factors } & \multirow{2}{*}{$\mathrm{N}$} & LY & 305-dMY & ADMY & LL \\
\hline & & $\mathrm{X} \pm \mathrm{S}_{\mathrm{x}}^{-}$ & $\mathrm{X} \pm \mathrm{S}_{\mathrm{x}}^{-}$ & $\mathrm{X} \pm \mathrm{S}_{\mathrm{x}}^{-}$ & $\mathrm{X} \pm \mathrm{S}_{\mathrm{x}}^{-}$ \\
\hline Calving season & & $*$ & NS & NS & $\mathrm{NS}$ \\
\hline Winter & 95 & $9290.2^{\mathrm{b}} \pm 248.9$ & $8323.3 \pm 217.1$ & $27.0 \pm 0.6$ & $315.8 \pm 3.0$ \\
\hline Spring & 47 & $9913.1^{\mathrm{a}} \pm 324.7$ & $8555.0 \pm 283.2$ & $27.4 \pm 0.9$ & $322.4 \pm 3.9$ \\
\hline Summer & 26 & $8979.2^{\mathrm{b}} \pm 380.6$ & $8108.4 \pm 331.9$ & $26.3 \pm 1.1$ & $308.7 \pm 4.6$ \\
\hline Autumn & 73 & $8968.4^{b} \pm 237.5$ & $8082.6 \pm 207.1$ & $26.2 \pm 0.6$ & $313.2 \pm 2.8$ \\
\hline General average & 241 & $9287.7 \pm 195.1$ & $8267.3 \pm 170.2$ & $26.7 \pm 0.5$ & $315.0 \pm 2.3$ \\
\hline Calving year & & *** & *** & $* * *$ & NS \\
\hline 1 & 7 & $7984.9^{\mathrm{b}} \pm 757.1$ & $6726.5^{\mathrm{b}} \pm 660.2$ & $19.9^{\mathrm{b}} \pm 2.0$ & $318.8 \pm 9.1$ \\
\hline 2 & 11 & $9590.0^{\mathrm{a}} \pm 596.1$ & $8210.6^{\mathrm{a}} \pm 519.8$ & $26.1^{\mathrm{a}} \pm 1.6$ & $321.3 \pm 7.1$ \\
\hline 3 & 33 & $9851.7^{\mathrm{a}} \pm 392.2$ & $8423.1^{\mathrm{a}} \pm 342.0$ & $26.8^{\mathrm{a}} \pm 1.0$ & $321.1 \pm 4.7$ \\
\hline 4 & 49 & $9665.8^{\mathrm{a}} \pm 313.1$ & $8481.0^{\mathrm{a}} \pm 273.0$ & $27.5^{\mathrm{a}} \pm 0.8$ & $314.6 \pm 3.7$ \\
\hline 5 & 55 & $10001.3^{\mathrm{a}} \pm 273.2$ & $8914.3^{\mathrm{a}} \pm 238.2$ & $30.2^{\mathrm{a}} \pm 0.7$ & $314.0 \pm 3.3$ \\
\hline 6 & 50 & $9230.8^{a} \pm 275.4$ & $8361.0^{\mathrm{a}} \pm 240.2$ & $27.9^{\mathrm{a}} \pm 0.7$ & $312.7 \pm 3.3$ \\
\hline $7 \geq$ & 36 & $8689.7^{\mathrm{a}} \pm 364.7$ & $8754.5^{\mathrm{a}} \pm 318.0$ & $28.8^{\mathrm{a}} \pm 0.9$ & $302.4 \pm 4.4$ \\
\hline General average & 241 & $9287.7 \pm 195.1$ & $8267.3 \pm 170.2$ & $26.7 \pm 0.5$ & $315.0 \pm 2.3$ \\
\hline Lactation number & & $* *$ & NS & $* *$ & NS \\
\hline 1 & 62 & $7758.7^{\mathrm{b}} \pm 275.1$ & $7622.1 \pm 239.9$ & $25.0^{\mathrm{b}} \pm 0.8$ & $307.9 \pm 3.3$ \\
\hline 2 & 58 & $9267.6^{\mathrm{a}} \pm 284.2$ & $8740.7 \pm 247.8$ & $28.7^{\mathrm{a}} \pm 0.8$ & $316.0 \pm 3.4$ \\
\hline 3 & 57 & $9849.0^{\mathrm{a}} \pm 313.2$ & $8604.7 \pm 273.1$ & $28.2^{\mathrm{a}} \pm 0.9$ & $318.2 \pm 3.8$ \\
\hline 4 & 44 & $9962.7^{\mathrm{a}} \pm 381.0$ & $8322.1 \pm 332.2$ & $27.3^{\mathrm{a}} \pm 1.1$ & $323.1 \pm 4.6$ \\
\hline $5 \geq$ & 20 & $9600.6^{\mathrm{a}} \pm 502.0$ & $8046.9 \pm 437.8$ & $26.4^{\mathrm{a}} \pm 1.4$ & $309.9 \pm 6.0$ \\
\hline General average & 241 & $9287.7 \pm 195.1$ & $8267.3 \pm 170.2$ & $26.7 \pm 0.5$ & $315.0 \pm 2.3$ \\
\hline
\end{tabular}

a,b: The difference between values with different letter in the same column is significant $(\mathrm{P}<0.05) ; *: \mathrm{P}<0.05 ; * *: \mathrm{P}<0.01 ; * * *: \mathrm{P}<0.001 ; \mathrm{NS}: \mathrm{Not}$ significant.

\section{Discussion}

In the present study, LY in Holstein cows, $(9356.2 \mathrm{~kg})$ is higher than the value reported by some researchers (Muir et al., 2004; Özcan, 1994; Haile-Mariam et al., 2003; Çerçi, 2006; Koçak et al., 2007; Parlak ve Kandır, 2015; Uzmay et al., 1998) while it is similar to those reported by other authors (Bayril and Yilmaz, 2010, Stanton et al.,1991; Wade and Van Vleck, 1989).

According to the obtained data, the effect of the calving year on LY is important. This finding is consistent with those reported by İnci et al. (2007), Özcan (1994) and Güneş (1999). The importance of the effect of the calving season is consistent with the studies conducted by İnci et al. (2007), Özcan (1994) and Güneş (1999). LY, was highest in the establishment in 2007 (8. year) and lowest in 2005 (6. year). The reason for this is thought to be that the environmental factors have had different effects over the years.

LY determined for the breed cows at this establishment in Sanliurfa was higher than other studies conducted in Turkey, we believe that the reason for this could be that Holstein cows in this establishment were well adapted to operating conditions and herd health management program was carried out successfully. Furthermore, if we consider that the CV of milk yield changes between $15-25 \%$, it can be said that the variation in milk yield is very high in the population.
305-dMY $(8549.15 \mathrm{~kg})$ value was found to be higher than that reported by some researchers (Atashi et al., 2012; Bakır and Çetin, 2003; Campos et al., 1994; Çerçi, 2006; Elzo et al., 2004; Hamşa, 2002; Kadarmideen et al., 2000; Mayne and McCoy, 2002; Pryce, 2003), while it was similar to that reproted by some other researchers (Cady, 1991; Gröhn and McDermott, 1999) and similar to that reported by others (Bayril and Y1lmaz, 2017; Ojango and Pollot, 2002). This indicates that the animals in the establishment where study was conducted constitute a well breeding herd and that the registration system is kept fastidiously and regularly.

In our study, the effects of calving age on 305-dMY were significant $(\mathrm{P}<0.05)$ while the effects of calving season, year and lactation number were insignificant $(\mathrm{P}>0.05)$. In Tunisia and Iran, it was found that the effect of the calving year and calving season on the milk yield was significant $(\mathrm{P}<0.01)$ (Ajili et al., 2007; Nilforooshan and Edriss, 2004).

The LL was calculated as 314.3 days in this study. While this value was higher than the value reported by some researchers (Abubakar et al., 1986; Catillo et al., 1995; Sehar ve Özbeyaz, 2005; Özçelik ve Arpacık, 2000), it was lower than that reproted by some other researchers (Akkaş, 2008; Çerçi, 2006; Haile-Mariam et al., 2003; Koçak et al., 2007; Parlak ve Kandır, 2015; Ojango and 
Pollot, 2002) and was similar to that calculated by some others (Bayril and Yılmaz, 2017; Doğan M, Kaygısız, 1999). This value appears to be about 9 days longer than the 305 day period, which is considered as the standard lactation time. In this study, the length of lactation indicates that cows could be milked for a long time in order to obtain more milk in the establishment.

As a result, it is concluded that calving season, calving year and lactation number have an impact on milk yield characteristics; it is suggested that higher lactation milk yield in this dairy establishment compared to other establishments in the region is achieved thanks to better adaptability along with well-maintained herd health and management.

\section{References}

Abubakar BY, Mcdowell RE, Van Vleck LD. 1986. Genetic Evaluation of Holsteins in Columbia, J Dairy Sci, 69: 10811086.

Afifi EA, Khalil MH, Salem MA. 1994. Evaluation of imported and locally born Friesian cows raised at commercial farms in Egypt. 1. Models and non-genetic effects. Anim Breed Abst, 62: 3001

Ajili N, Rekik B, Ben Gara A, Bouraoui R. 2007. Relationships among milk production, reproductive traits, and herd life for Tunisian Holstein-Frisean cows, African J Agri Res, 2: $47-$ 51.

Akkaş Ö, Şahin EH. 2008. Holştayn Irkı Sığırlarda Bazı Verim Özellikleri, Kocatepe Vet J, 1: 25-31.

Ali AKA, Al-Jumaah RS, Hayes E. 1996. Lactation curve of Holstein Friesian cows in the Kingdom of Saudi Arabia. Asian-Australasian J Anim Sci, 9: 439-447.

Alpan O, Aksoy AR. 2015. Sığır Yetiştiriciliği ve Besiciliği. 7.basim, ISBN: 975-95445-0-4, İstanbul.

Atashi H, Zamiri MJ, Sayyadnejad MB, Akhlaghi A. 2012. Trends in the reproductive performance of Holstein dairy cows in Iran, Trop Anim Health Pro, 44, 2001-2006.

Bakır G, Çetin M. 2003. Reyhanlı Tarım İşletmesinde yetiştirilen Siyah Alaca sığırlarda döl ve süt verim özellikleri, Türk J Vet Anim Sci, 27: 173-180.

Bayrıl T, Y1lmaz O. 2010. Kazova Vasfi Diren Tarım İşletmesinde yetiştirilen Siyah Alaca sığırların döl verim özellikleri, YYÜ Vet Fak Derg, 21: 163-167.

Bayrıl T, Yılmaz O. 2017. Holştayn Sütçü İneklerde Süt Verim Performanslarına Buzağı Cinsiyeti, Servis Periyodu, Doğum Sayısı ve Buzağılama Mevsiminin Etkisi, Dicle Üniv Vet Fak Derg, 10: 89-94.

Cady RA. 1991. Combined effects of primiparous age and first calving interval on production trough two lactation for Holstein herds in Washington. J Dairy Sci, 74: 279.

Campos MS, Wilcox CJ, Becerril CM, Diz A. 1994. Genetic Parameters for Yield and Reproductive Traits of Holstein and Jersey Cattle in Florida, J Dairy Sci, 77: 867-873.

Catillo G, Kadlecik O, Moioli B. 1995. Genetic Evaluation of Selected Holstein Population With An Animal Model for Milk Production. Zivocisna Vyroba, 40: 529-532.

Çerçi S. 2006. Aydın ilinde bazı işletmelerde yetiştirilen SiyahAlaca süt sığırlarının süt ve Döl Verim Özellikleri ile dış görünüşlerine göre Sinıflandırılması. Adnan Menderes Üniversitesi Fen Bilimleri EnstitüsüYüksek LisansTezi. 83 s., Aydın.

Doğan M, Kaygisız A. 1999. Türkiye'deki İsviçre Esmer sığırlarda süt protein polimorfizmi ile süt verim özellikleri arasındaki ilişkiler. Türk J Vet Anim Sci, 23: 47-49.

Elzo MA, Jara A, Barria N. 2004. Genetic Parameters and Trends in The Chilean Multibreed Dairy Cattle Population, J Dairy Sci, 87: 1506-1518.
FAO, 2018. Food and Agriculture Organization of The United Nations. http://faostat.fao.org/site/569/default.aspx\#ancor, Erişim tarihi: 20.01.2018.

Gröhn Y, McDermott JJ. 1999. Analysis of correlated continuous repeated observations: Modelling the effect of ketosis on milk yield in dairy cows. Pre Vet Med, 39: 137-153.

Güneş H. 1999. Kumkale Tarım İşletmesinde 10 yıllık siyah alaca sığır yetiștiriciliği üzerine araştırmalar. 2. süt verim özellikleri. İstanbul Üniv Vet Fak Derg, 22: 225-240.

Haile-Mariam M, Bowman PJ, Goddard ME. 2003. Genetic and enviromental relationship among calving interval, survival, persistency of milk yield and somatic cell count in dairy cattle. Liv Pro Sci, 80: 189-200.

Hamşa H. 2002. Ceylanpınar Tarım İşletmesi'nde yetiştirilen Siyah Alaca sığırlarda yetiștirme ve süt verim özellikleri. Yüzüncü Y1l Üniversitesi Fen Bilimleri Enstitüsü Zootekni AD, Yüksek Lisans Tezi, 2002, Van.

İnci S, Kaygısız A, Efe E, Baş S. 2007. Altınova Tarım İşletmesinde Yetiştirilen Esmer Sığırların Süt ve Döl Verim Özellikleri. Ankara Üniv Zir Fak Tar Bil Derg, 13:203-212.

Kadarmideen HN, Thompson R, Simm G. 2000. Linear and threshold Model Genetic Parameters for Disease, Fertility and Milk Production in Dairy Cattle. Anim Sci, 71: 411-419.

Koçak S, Yüceer B, Uğurlu M, Özbeyaz C. 2007. Bala Tarım İşletmesinde yetiştirilen Holştayn ineklerde bazı verim özellikleri. Lalahan Hay Araşt Enst Derg, 47: 9-14.

Lackovic M, Ukalovic M, Mendler Z, Rizar S. 1995. Some characteristics of the Holstein breed in Slovenia. 2. Milk production in Slovenia. Anim Breed Abst, 63: 7038.

Mayne CS, McCoy MA. 2002. Fertility of dairy cows in northen Ireland. Vet Rec, 150: 707-713.

Muir BL, Fatehi J, Schaeffer LR. 2004. Genetic Relationships Between Persistency and Reproductive Performance in First Lactation Canadian Holsteins, J Dairy Sci, 87: 3029-3037.

Nilforooshan MA, Edriss MA. 2004. Effect of age at first calving on some productive and longevity Traits in İranian Holsteins of the Isfahan Provinz, J Dairy Sci, 87: 2130-2135.

Ojango JMK, Pollot GE. 2002. The relationship between Holstein bull breeding values form milk yield derived in both the UK and Kenya. Liv Pro Sci, 74: 1-12.

Özcan M. 1994. Siyah alaca sığırlarda yaşama gücü, döl verimi ve süt verimi özelliklerini etkileyen bazı çevresel faktörler üzerinde araştırmalar, İstanbul Üniversitesi Sağlık Bilimleri Enstitüsü, Doktora Tezi, İstanbul.

Özçelik M, Arpacık R. 2000. Siyah Alaca sığırlarda laktasyon sayısının süt ve döl verimine etkisi. Turk J Vet Anim Sci, 24: 39-44.

Parlak N, Kandır EH. 2015. Afyonkarahisar İlinde Yetiştirilen Siyah Alaca İneklerin Süt ve Döl Verimleri Üzerine Farklı Çevre Faktörlerinin Etkisi, Kocatepe Vet J, 8: 11-17.

Polanski S, Czaja H, Wrobel A, Trela J. 1993. The effect of some factors on dairy performance of black-and-white cows at the Chorzelow experiment farm. Anim Breed Abst, 61: 5962.

Pryce JE. 2003. Genetic aspects of common health disorders and measures of fertility in Holstein Friesian dairy cattle, Anim Sci, 65: 353-360.

Sehar O, Özbeyaz C. 2005. Orta Anadolu'daki bir işletmede Holştayn ırkı sığırlarda bazı verim özellikleri. Lalahan Hayv Araşt Ens Derg, 45: 9-19.

Souza EM de, Milagres JC, Martinez ML, Regazzi AJ, Silva M de AE. 1996. Effects of genetic and environmental factors on lactation length in Gir dairy herds. Anim Breed Abst, 64: 104.

Stanton TL, Blake RW, Quaas RL, Van Vleck LD, Carabona MJ. 1991. Genotype By Environment interaction for Holstein Milk Yield in Colombia, Mexico, and Puerto Rico, J Dairy Sci, 74: 1700-1714.

Thaler Neto A, Neiva RS, Oliveira AIG de, Martines ML, Falco JE. 1996. Causes of variation in the performance of Holstein cattle in Santa Caterina State. Lactation duration. Anim Breed Abst, 64: 106. 
Udedibie ABI, Umo I, Shaibu I. 1985. The Vom Herd. II. Effect of lactation number and season of calving on lactational characteristics of imported Friesian cows. J Anim Prod Res, 5: $31-44$.

Uğur F. 2014. Sığır Yetiştirme (Ders Kitabı). Çanakkale Onsekiz Mart Üniversitesi Yayınları No: 117. Birinci bask1. Pozitif Matbaa. ISBN: 978-605-4222-36-0, Çanakkale.
Uzmay C, Kaya A, Kaya İ, Akbaş Y, Saçlı Y. 1998. İzmir, Manisa ve Aydın illerinde Türk-ANAFİ projesi kapsamındaki işletmelerde İtalya'dan gelen ve Türkiye'de doğan SiyahAlaca ineklerin bazı verim özelliklerinin karşılaştırılmalı analizi. Ege Bölgesi 1. Tarım Kongresi. II. Cilt. 7-11 Eylül 1998. ADÜ Zir Fak Aydın.

Wade KM, Van Vleck LD. 1989. Genetic Parameters for Production Traits of Holsteins in California, New York, and Wisconsin. J Dairy Sci, 72: 1280-1285. 